\title{
The Effect of Cold Working on Creep Rupture Strength and Microstructure of Ni-23Cr-7W Alloy
}

\author{
Yoshiki Shioda', Keiji Kubushiro', Youhei Sakakibara1, Kyohei Nomura', Yoshinori Murata² \\ ${ }^{1}$ Research Laboratory, IHI Corporation, Yokohama, Japan \\ ${ }^{2}$ Department of Materials, Physics and Energy Engineering, Nagoya University, Nagoya, Japan \\ Email: yoshiki_shioda@ihi.co.jp
}

How to cite this paper: Shioda, Y., Kubushiro, K., Sakakibara, Y., Nomura, K. and Murata, Y. (2017) The Effect of Cold Working on Creep Rupture Strength and Microstructure of Ni-23Cr-7W Alloy. World Journal of Mechanics, 7, 283-295.

https://doi.org/10.4236/wjm.2017.710023

Received: September 11, 2017

Accepted: October 27, 2017

Published: October 30, 2017

Copyright $\odot 2017$ by authors and Scientific Research Publishing Inc. This work is licensed under the Creative Commons Attribution International License (CC BY 4.0).

http://creativecommons.org/licenses/by/4.0/

\begin{abstract}
In order to clarify the reason why the creep rupture time of pre-strained $\mathrm{Ni}-23 \mathrm{Cr}-7 \mathrm{~W}$ Alloy (HR6W) is longer than that of the non-pre-strained HR6W, microstructures of HR6W after a series of creep tests were investigated. The creep tests were conducted at $750^{\circ} \mathrm{C}, 90$ and $100 \mathrm{MPa}$. In the pre-strained samples, the grain boundary shielding ratio by precipitates was larger than that of the non-pre-strained sample. In addition, in the pre-strained samples the size of the $\mathrm{M}_{23} \mathrm{C}_{6}$ carbide in the grains was finer than in the non-pre-strained sample. The $\mathrm{W}$ content in the $\mathrm{M}_{23} \mathrm{C}_{6}$ carbide in the pre-strained samples tended to be larger than in the non-pre-strained sample. Therefore, the Ostwald ripening of the carbide was delayed and the size of $\mathrm{M}_{23} \mathrm{C}_{6}$ carbide was thought to be fine for a long time. These observations show that creep strength in the pre-strained samples is higher than that of the non-pre-strained sample because of both precipitation strengthening inside of the grains and grain boundaries.
\end{abstract}

\section{Keywords}

A-USC, HR6W, Cold Working, Creep Strength, Grain Boundary Shielding Ratio, $\mathrm{M}_{23} \mathrm{C}_{6}$ Carbide

\section{Introduction}

For coal-fired power plants, the technology of the Advanced-Ultra Super Critical (A-USC) boilers is being developed with the purpose of enhancing generation efficiency and reducing $\mathrm{CO}_{2}$ emissions [1]-[6]. The steam temperature of A-USC boilers will be $100^{\circ} \mathrm{C}$ higher than that of the conventional $600^{\circ} \mathrm{C}$-class Ultra Super Critical (USC) boilers [7]. Therefore, Ni-based alloys are planned to be used in A-USC boilers. As the Ni-based alloy, currently, Ni-23Cr-7W Alloy (HR6W) is receiving attention as a candidate material for A-USC boilers [8]. The creep strength 
of $\mathrm{HR} 6 \mathrm{~W}$ is enhanced by precipitation strengthening on the Laves phase and $\mathrm{M}_{23} \mathrm{C}_{6}$ carbide. HR6W has excellent high-temperature ductility and thermal fatigue characteristics compared to other Ni-based alloys [9]. Boiler tubes are generally subject to bending in manufacturing process. Austenitic stainless steels are used for boiler tubes of USC boilers. There are many reports about the effect of cold working on the creep strength of austenitic stainless steels [10] [11] [12] [13] [14]. At the short-time conditions, the creep rupture strength of cold-worked austenitic stainless steels is significantly higher than that of the non-cold-worked austenitic stainless steels. On the other hand, at the long-time conditions, the creep rupture strength of cold-worked austenitic stainless steels is similar to that of non-cold-worked austenitic stainless steels [11]. It has been clarified that this characteristic results from aggregation and coarsening of carbide. Conversely, with regards to HR6W, Okada et al. reported that creep rupture time of HR6W that was subjected to cold working by up to $30 \%$ at room temperature increases approximately 100 times than HR6W that was not subjected to cold working and the creep strength is stable for a long time [15]. Saito et al. reported that the increase in the creep rupture time of HR6W that was subjected to cold working of $20 \%$ was maintained in a long-term test of 70,000 h or more [16]. In addition, Kubushiro et al. reported that the increase in creep rupture time of cold-worked HR6W is remarkably large as compared with other cold-worked Ni-based alloys [17]. However, there has been almost no discussion on the mechanism of this increase in strength.

The purpose of this study is to clarify the reason why the creep rupture time of cold-worked HR6W is longer than that of the non-cold-worked HR6W. For this purpose, the pre-strained HR6W was prepared via interrupted tensile test and microstructures of HR6W after a series of creep tests were investigated.

\section{Experiment Method}

In this study, two heats of HR6W tube materials were used as test materials. The tubes were subjected to solution heat treatment. The chemical composition of HR6W is shown in Table 1. For simulating the cold work, among the test materials, Alloy A was processed into arc-shaped tensile test specimens, i.e., cross-section of the specimens is arc-shaped. The arc-shaped specimens were parallel portion with a width $15 \mathrm{~mm}$, a thickness $8 \mathrm{~mm}$, and a gauge distance $70 \mathrm{~mm}$. Tensile interrupted tests were carried out on them. The specimens were subjected to pre-strain of $10 \%$ and $15 \%$. They are referred to as the pre-strained samples. After the interrupted tensile test, the parallel portion of each test specimen was re-processed

Table 1. Chemical composition of HR6W.

\begin{tabular}{cccccccccccc}
\hline & $\mathrm{C}$ & $\mathrm{Si}$ & $\mathrm{Mn}$ & $\mathrm{P}$ & $\mathrm{S}$ & $\mathrm{Ni}$ & $\mathrm{Cr}$ & $\mathrm{W}$ & $\mathrm{Ti}$ & $\mathrm{Nb}$ & $\mathrm{Fe}$ \\
\hline Alloy A & 0.070 & 0.15 & 1.02 & 0.008 & $<0.01$ & Bal. & 23.37 & 7.54 & 0.09 & 0.18 & 22.06 \\
Alloy B & 0.080 & 0.20 & 1.15 & 0.008 & 0.002 & Bal. & 22.80 & 8.00 & 0.11 & 0.19 & 22.0 \\
\hline
\end{tabular}


into a specimen with gauge length of $30 \mathrm{~mm}$ and a parallel portion of $6 \mathrm{~mm}$ for creep tests.

The Vickers hardness of the $0 \%, 10 \%$, and $15 \%$ pre-strained samples were 146 , 190, and $207 \mathrm{HV}$, respectively. Dislocation density measurements were conducted by XRD on the initial samples [18] [19]. Creep tests in the pre-strained samples (Alloy A) were conducted at $750^{\circ} \mathrm{C}, 100 \mathrm{MPa}$. Creep rupture test was conducted in the $0 \%$ pre-strained sample; whereas creep interrupted tests were conducted in the $10 \%$ and $15 \%$ pre-strained samples. In addition, Alloy B was processed into creep test specimen with gauge length of $30 \mathrm{~mm}$ and a parallel portion of $6 \mathrm{~mm}$ and creep test was conducted (hereafter, it is referred to as the non-pre-strained sample). Creep rupture test in the non-pre-strained sample was conducted at $750^{\circ} \mathrm{C}, 90 \mathrm{MPa}$. Each of the ruptured or interrupted test specimen was cut such that the surface to be observed was parallel with the stress axis. The creep voids and cracks were observed with an optical microscope (OM). The $\mathrm{M}_{23} \mathrm{C}_{6}$ carbide on grain boundaries and Laves phases on grain boundaries or in the grains were observed with the backscattered electron of a scanning electron microscope (SEM) under the conditions of an acceleration voltage of 15 $20 \mathrm{kV}$ and $\mathrm{WD}=5 \mathrm{~mm}$. Figure 1 shows a flow diagram of experimental procedure. In addition, the grain boundary shielding ratio $\rho$ was calculated using Expression (1) [20].

$$
\rho=1-\sum \lambda i / L
$$

In this expression, $\lambda_{i}$ is the length of the grain boundary that does not contain precipitates, and $\mathrm{L}$ is the total length of all the grain boundaries.

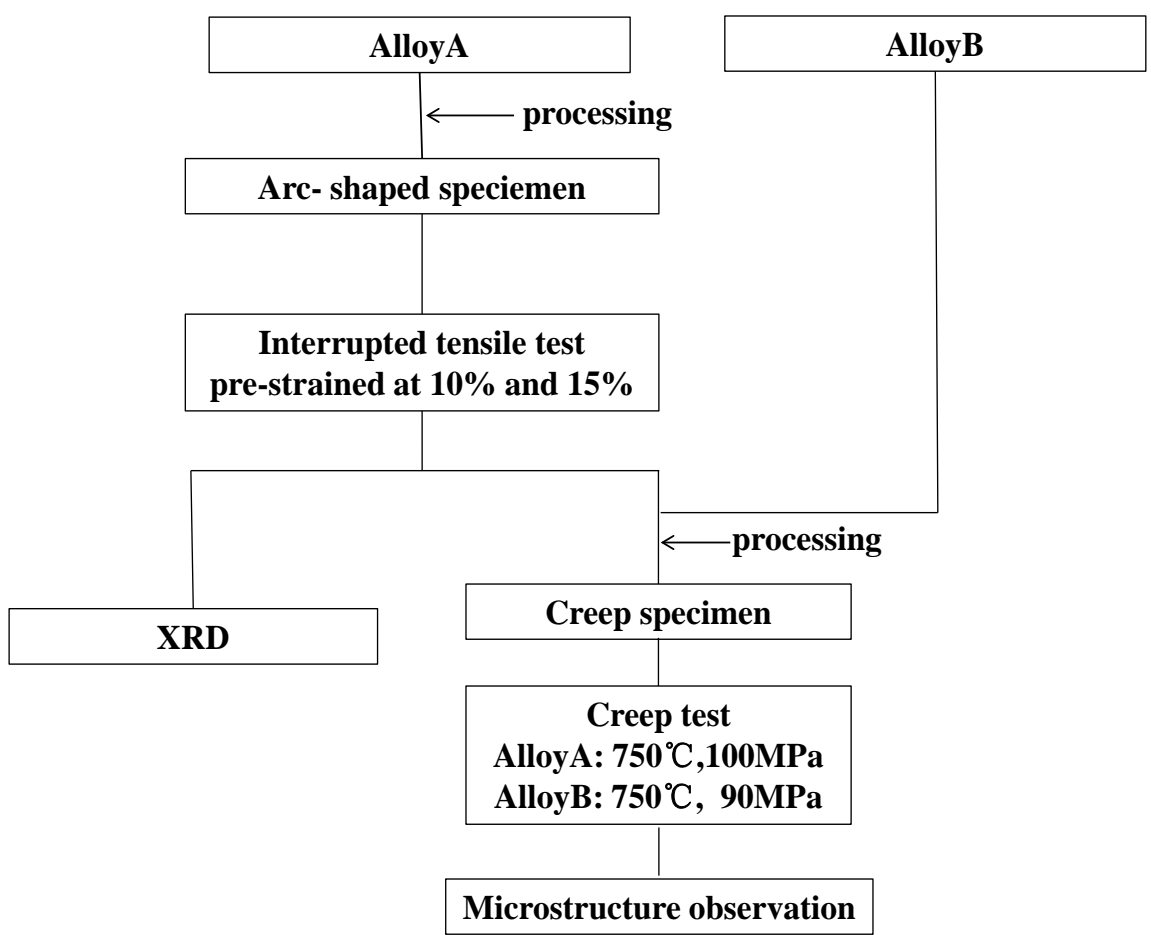

Figure 1. Flow diagram of experimental procedure. 
In order to evaluate the fine $\mathrm{M}_{23} \mathrm{C}_{6}$ carbide contained in the grains, carbon extraction replicas of the non-pre-strained sample and the pre-strained samples were prepared and scanning transmission electron microscope (STEM) observations were conducted. STEM observations of the $\mathrm{M}_{23} \mathrm{C}_{6}$ carbide were conducted under the condition of an acceleration voltage of $200 \mathrm{kV}$. In order to quantitatively evaluate the composition of $\mathrm{M}_{23} \mathrm{C}_{6}$ carbide, EDX analysis on 30 pieces was conducted.

\section{Results and Discussion}

\subsection{Effect of Pre-Strain on Creep Rupture Strength}

Figure 2 shows the effect of pre-strain on the creep rupture time of HR6W. The vertical axis indicates the ratio between the creep rupture time of the pre-strained sample and that of the non-pre-strained sample. The horizontal axis indicates the degree of cold working. The black circles correspond to the results of the creep tests on the pre-strained samples (Alloy A). Figure 1 also indicates the results reported by Okada et al. [15]. The result for the $0 \%$ pre-strained sample was obtained from the creep rupture test, in which the sample was ruptured in approximately $1000 \mathrm{~h}$. On the other hand, the results for the $10 \%$ and $15 \%$ pre-strained samples were obtained in a $10,000 \mathrm{~h}$ interrupted test. These results indicate that cold-worked HR6W significantly increases its creep rupture time, as reported by Okada et al. and Saito et al. [15] [16]. To clarify the cause of this increase, the microstructures of the $10 \%$ and $15 \%$ pre-strained samples (samples interrupted at $750^{\circ} \mathrm{C}, 100 \mathrm{MPa}$ for $10,400 \mathrm{~h}$ ) and that of the non-pre-strained sample that was subjected to a test of practically the same duration (Alloy B material ruptured at $750^{\circ} \mathrm{C}, 90 \mathrm{MPa}$ for $11,010 \mathrm{~h}$ ) were compared.

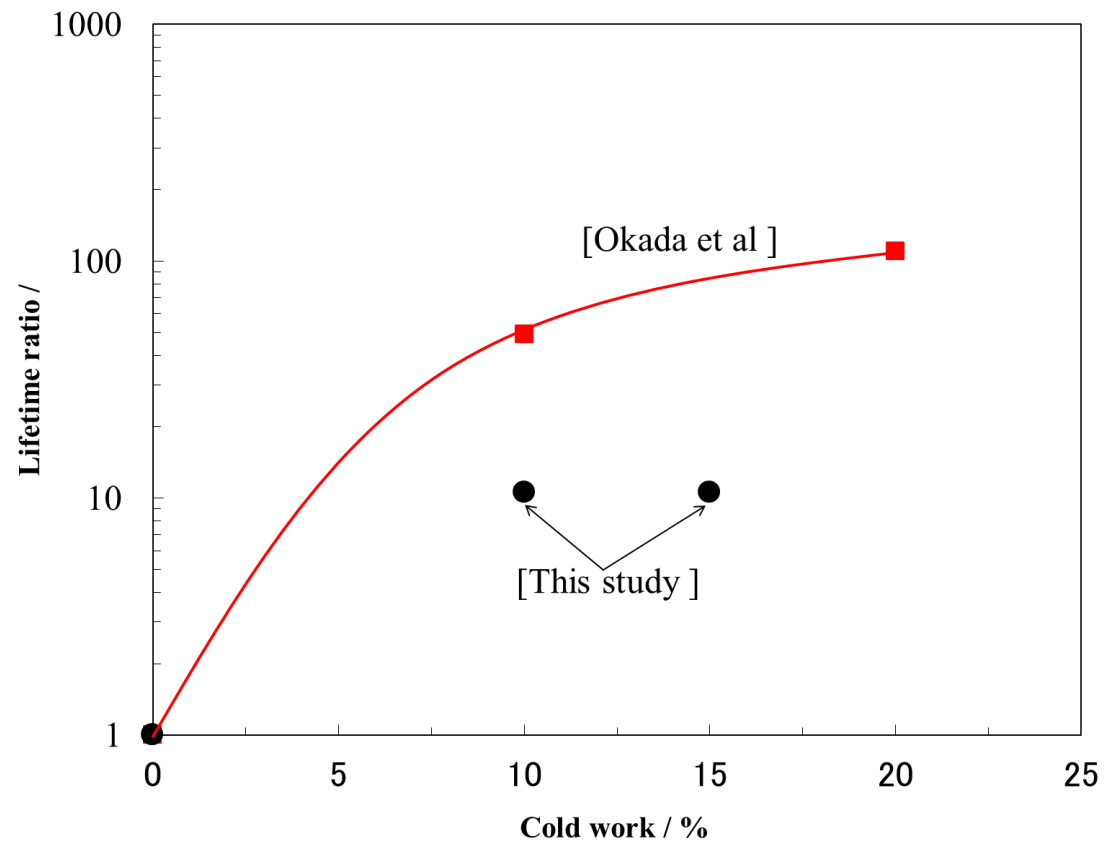

Figure 2. The effect of pre-strain on the creep rupture time of HR6W. 


\subsection{Difference in the Microstructures of the Non-Pre-Strained Sample and Pre-Strained Samples}

Figure 3 shows OM images taken from non-pre-strained sample and pre-strained samples. Figure 3(a) shows the microstructure of the non-pre-strained sample ruptured at $750^{\circ} \mathrm{C}, 90 \mathrm{MPa}$ for $11,010 \mathrm{~h}$. Figure $3(\mathrm{~b})$ and Figure $3(\mathrm{c})$ show the microstructures of the $10 \%$ and $15 \%$ pre-strained samples interrupted at $750^{\circ} \mathrm{C}$, $100 \mathrm{MPa}$ for $10,400 \mathrm{~h}$, respectively. In the image of the non-pre-strained sample shown in Figure 3(a), cracks initiated at the grain boundaries. On the other hand, in the images of the $10 \%$ and $15 \%$ pre-strained samples, voids and cracks were not observed at the grain boundaries, despite the fact that the samples were subjected to tests of practically the same duration as the test on the non-pre-strained sample. To clarify the cause, SEM observations of the grain boundaries in the non-pre-strained sample and the pre-strained samples were conducted.

\subsection{The Effect of Pre-Strain on the Precipitates near Grain Boundaries}

Figure 4 shows backscattered electron images of grain boundaries. Figure 4(a) shows the microstructure of the non-pre-strained sample ruptured at $750^{\circ} \mathrm{C}, 90$ MPa for 11,010 h. Figure 4(b) and Figure 4(c) show the microstructures of the $10 \%$ and $15 \%$ pre-strained samples interrupted at $750^{\circ} \mathrm{C}, 100 \mathrm{MPa}$ for $10,400 \mathrm{~h}$, respectively.

Precipitates of white color are Laves phase, and precipitates of gray color are $\mathrm{M}_{23} \mathrm{C}_{6}$ carbide. The amount of precipitates on the grain boundaries in the pre-strained samples was larger than that in the non-pre-strained sample. Therefore, the grain boundary shielding ratio by precipitates in the non-pre-strained sample and in the pre-strained samples were calculated from Equation (1). Figure 5 shows the results of the calculations. The grain boundary shielding ratio by precipitates in the non-pre-strained sample was approximately $55 \%$, whereas in the pre-strained samples it was $90 \%$ or higher. This is considered to be due to dislocations introduced by Pre-strain become precipitation sites and they accelerate precipitation [20] [21]. Takeyama et al. reported that in Ni-based alloys,
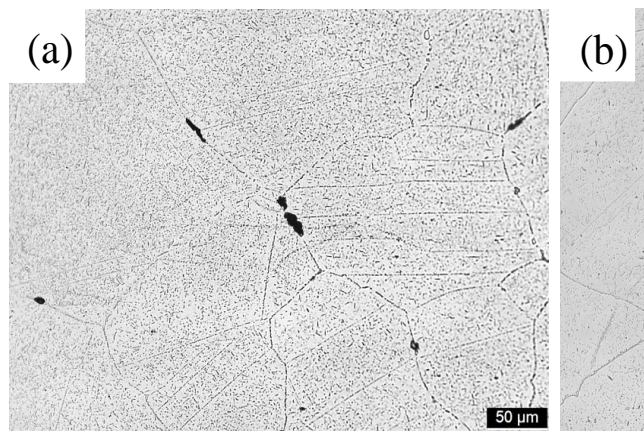

(c)

Figure 3. $\mathrm{OM}$ images of $\mathrm{HR} 6 \mathrm{~W}$ ruptured at $750^{\circ} \mathrm{C}, 90 \mathrm{MPa}$ for $11,010 \mathrm{~h}\left((\mathrm{a})\right.$ virgin) and interrupted at $750^{\circ} \mathrm{C}, 100 \mathrm{MPa}$ for 10,400 h ((b) pre-strained at $10 \%$ (c) pre-strained at $15 \%)$. 

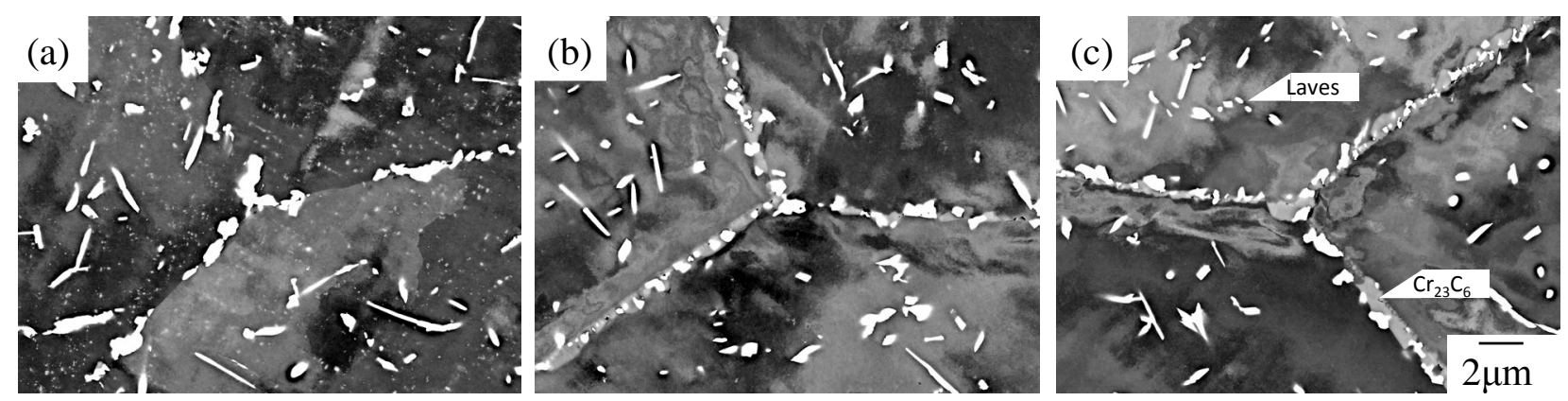

Figure 4. Backscattered electron images of grain boundaries for HR6W ruptured at $750^{\circ} \mathrm{C}, 90 \mathrm{MPa}$ for $11,010 \mathrm{~h}((\mathrm{a})$ virgin) and interrupted at $750^{\circ} \mathrm{C}, 100 \mathrm{MPa}$ for $10,400 \mathrm{~h}((\mathrm{~b})$ pre-strained at $10 \%$ (c) pre-strained at $15 \%)$.

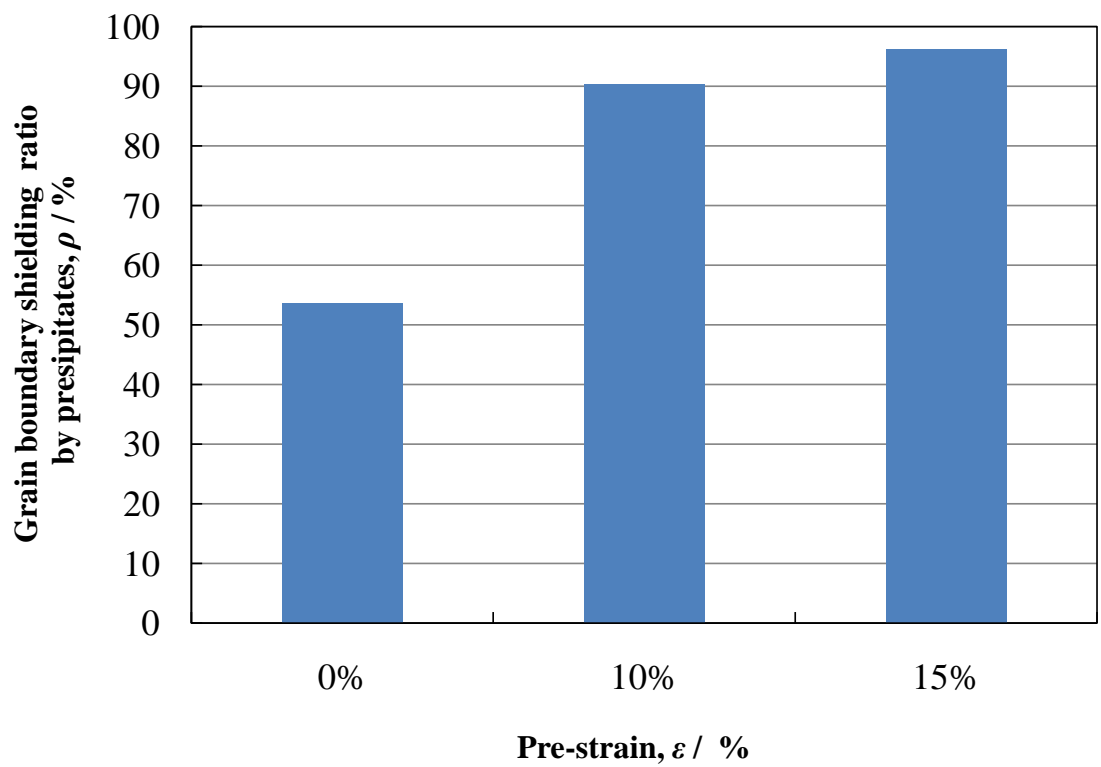

Figure 5. The ratio of grain boundary shielding by precipitates in $\mathrm{HR} 6 \mathrm{~W}$ crept at $750^{\circ} \mathrm{C}$ for $11,010 \mathrm{~h}$ without pre-strain and at $750^{\circ} \mathrm{C}$ for $10,400 \mathrm{~h}$ with pre-strain.

creep rupture strength increases with increase in the grain boundary shielding ratio by precipitates [22] [23] [24]. One of the reasons why in this way, the creep rupture strength of the pre-strained samples increased more than that of the non-pre-strained sample is considered to be the increase in the grain boundary shielding ratio by precipitates due to pre-strain.

\subsection{The Effect of Pre-Strain on Precipitates in the Grains}

In the previous section, it was found that the grain boundary shielding ratio differs depending on whether or not pre-strain is applied. Next, the intragranular microstructures in the non-pre-strained sample and the pre-strained samples were examined in order to clarify the effect of pre-strain on the precipitates in the grains. Since the size of Laves phase and $\mathrm{M}_{23} \mathrm{C}_{6}$ carbide in the grains are different, Laves phase and $\mathrm{M}_{23} \mathrm{C}_{6}$ carbide were observed by backscattered electron images and by STEM bright field images, separately.

Figure 6 shows backscattered electron images of Laves phase in the grains. 
Figure 6(a) shows the images of the non-pre-strained sample ruptured. Figure 6(b) and Figure 6(c) show the images of the $10 \%$ and $15 \%$ pre-strained samples interrupted, respectively. The needle-like precipitates of white color are Laves phase. Figure 7 shows the average diameters of Laves phase that were calculated as equivalent circle diameters from the analysis of the backscattered electron images. The average diameters of Laves phase were $0.5-0.6 \mu \mathrm{m}$ in the non-pre-strained sample and pre-strained samples. This fact suggests that pre-strain has almost no effect on the size of Laves phase.

Figure 8 shows STEM images and the results of EDX analysis in the non-pre-strained sample and the pre-strained samples. Figure 8(a) and Figure 8 (d) correspond to the non-pre-strained sample. Figure $8(\mathrm{~b})$ and Figure $8(\mathrm{e})$ correspond to the $10 \%$ pre-strained sample. Figure $8(\mathrm{c})$ and Figure $8(\mathrm{f})$ correspond to the $15 \%$ pre-strained sample. From the results of the EDX analysis shown in Figure 8(d), Figure 8(e), and Figure 8(f), the Cr-rich precipitates in
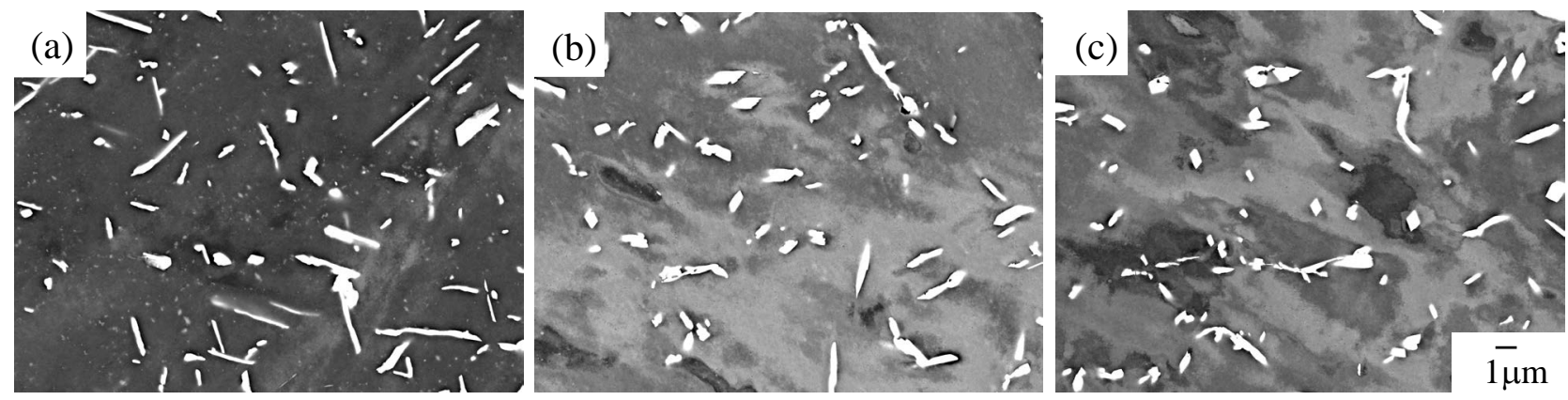

Figure 6. Backscattered electron images of intragranular grain for $\mathrm{HR} 6 \mathrm{~W}$ ruptured at $750^{\circ} \mathrm{C}, 90 \mathrm{MPa}$ for $11,010 \mathrm{~h}((\mathrm{a})$ virgin) and interrupted at $750^{\circ} \mathrm{C}, 100 \mathrm{MPa}$ for $10,400 \mathrm{~h}((\mathrm{~b})$ pre-strain at $10 \%$ (c) pre-strain at $15 \%)$.

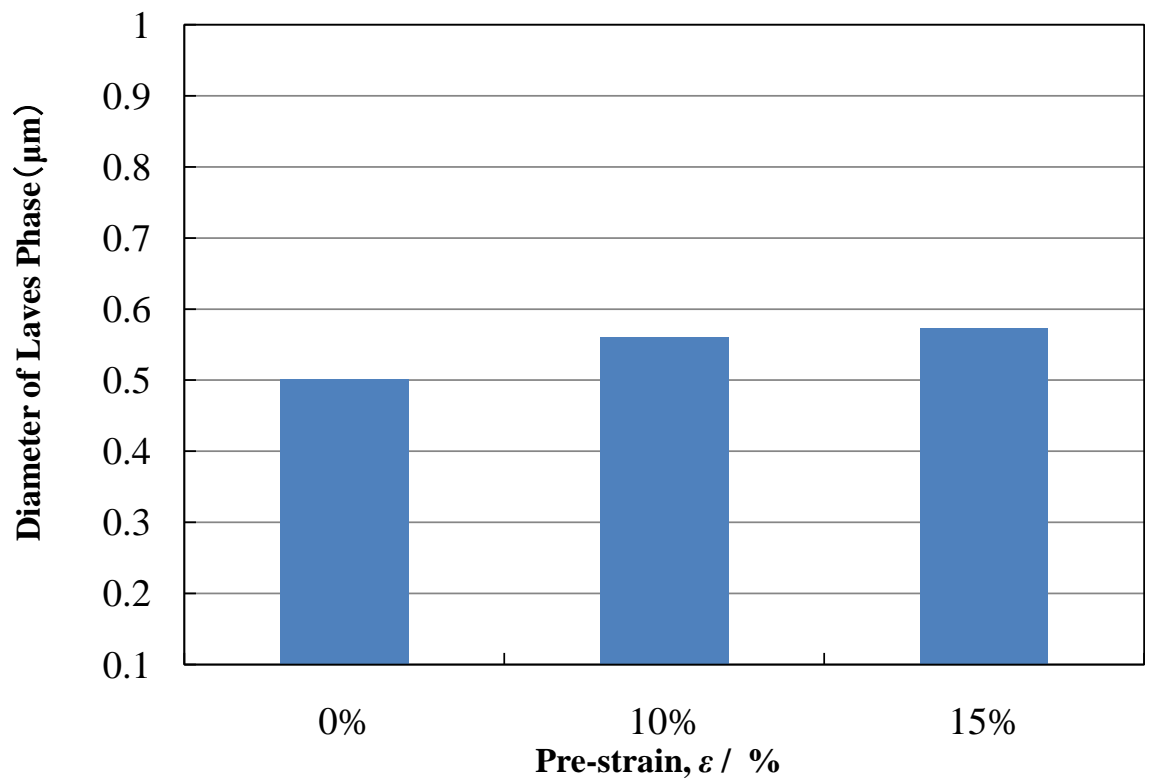

Figure 7. The average diameters of Laves phase for HR6W in virgin alloy after creep ruptured at $750^{\circ} \mathrm{C}, 90 \mathrm{MPa}$ for $11,010 \mathrm{~h}$ and pre-strained alloy after creep interrupted at $750^{\circ} \mathrm{C}, 100 \mathrm{MPa}$ for $10,400 \mathrm{~h}$. 
(a)
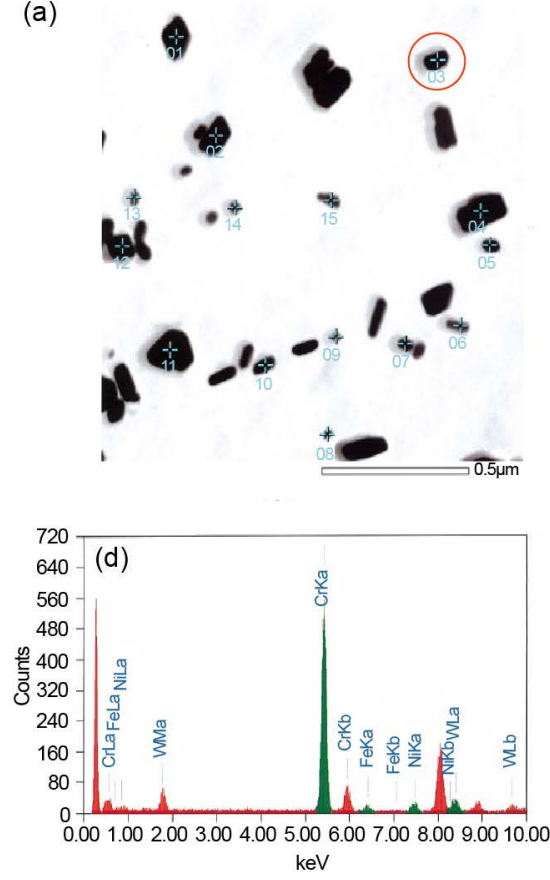

(b)
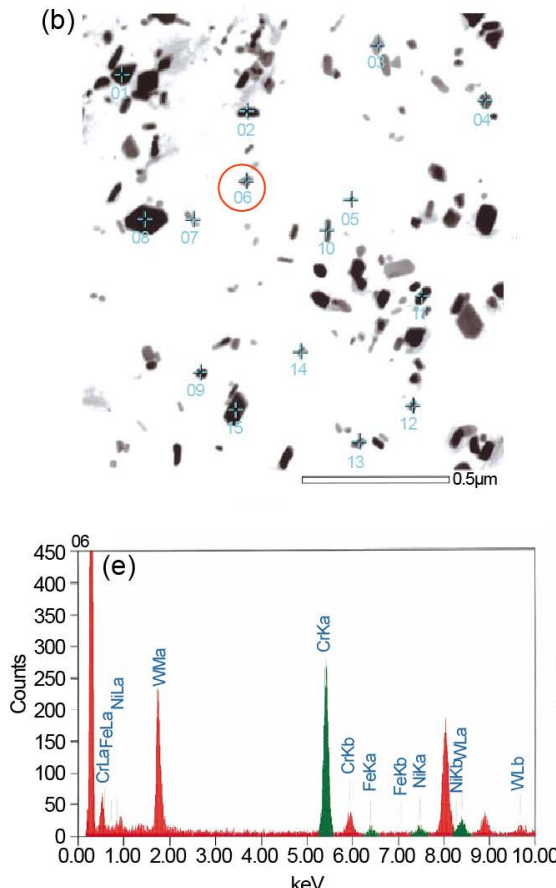

(c)
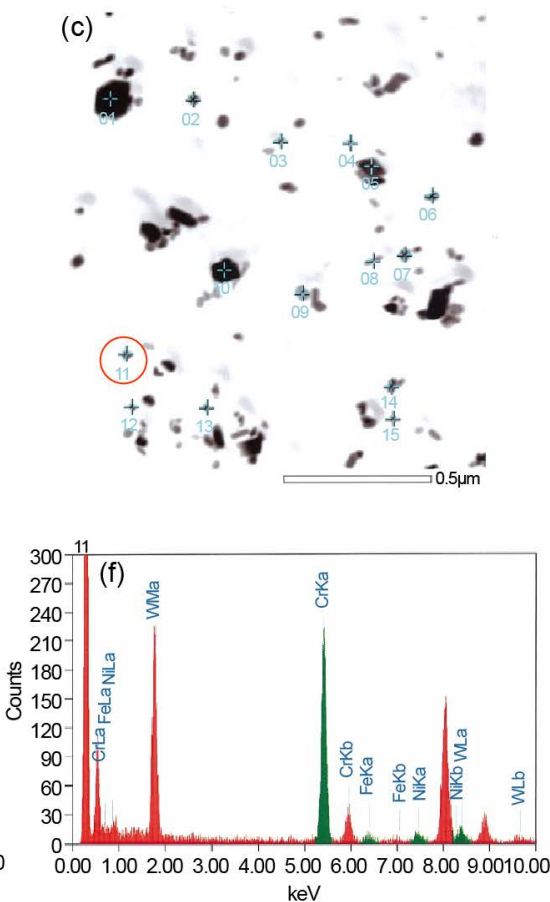

Figure 8. Scanning transmission electron images ((a) virgin (b) pre-strained at $10 \%$ (c) pre-strained at 15\%) and results of EDX analysis taken from the precipitates in grains of HR6W ((d) virgin (e) pre-strained at 10\% (f) pre-strained at 15\%).

the grains were identified as $\mathrm{M}_{23} \mathrm{C}_{6}$ carbide. The peak relative intensity of $\mathrm{W}$ increased with the increase in pre-strain. Form the results of STEM images shown in Figures 8(a)-(c), it is found that the size of $\mathrm{M}_{23} \mathrm{C}_{6}$ carbide in the pre-strained samples is finer than that in the non-pre-strained sample. From the STEM images of each sample, the sizes of the $\mathrm{M}_{23} \mathrm{C}_{6}$ carbide were calculated as equivalent circle diameters.

Figure 9 shows histograms of the diameters of $\mathrm{M}_{23} \mathrm{C}_{6}$ carbide. In the non-prestrained sample, the diameters of $\mathrm{M}_{23} \mathrm{C}_{6}$ carbide took a size randomly in the range from 20 to $100 \mathrm{~nm}$, and their average diameter was approximately $50 \mathrm{~nm}$. On the other hand, in the pre-strained samples, the diameters of the $\mathrm{M}_{23} \mathrm{C}_{6}$ carbide reached its peak at 20 to $40 \mathrm{~nm}$, and the average diameter of $\mathrm{M}_{23} \mathrm{C}_{6}$ carbide in the $10 \%$ and $15 \%$ pre-strained samples were $35 \mathrm{~nm}$ and $30 \mathrm{~nm}$, respectively. These findings clearly show that pre-strain contributes to the formation of finer $\mathrm{M}_{23} \mathrm{C}_{6}$ carbide in the grains. The cause of the formation of finer $\mathrm{M}_{23} \mathrm{C}_{6}$ carbide in the pre-strained samples compared to in the non-pre-strained sample is considered to be from the difference in initial dislocation density due to cold working. A number of studies have reported that the size of precipitates formed on dislocations have finer than that of precipitates formed in the matrix [25] [26] [27] [28]. In addition, studies based on energetics have reported that dislocations act as preferential nucleation sites for precipitates and reduce the critical nucleus radius in preferential nucleation [29] [30]. Therefore, dislocation density measurements were conducted by XRD on the initial samples that were not subjected to the creep test. 
Figure 10 shows the results of the measurements. The dislocation density of the non-pre-strained sample was $5.3 \times 10^{13} \mathrm{~m}^{-2}$, whereas the dislocation density of the $10 \%$ pre-strained sample and of the $15 \%$ pre-strained sample were $1.16 \times$ $10^{14} \mathrm{~m}^{-2}$ and $1.72 \times 10^{14} \mathrm{~m}^{-2}$, respectively. Accordingly, it is suggested that the reason for the formation of finer $\mathrm{M}_{23} \mathrm{C}_{6}$ carbide in the pre-strained samples is that $\mathrm{M}_{23} \mathrm{C}_{6}$ carbide precipitated on dislocations introduced by pre-strain.

There are reports that in Ni-base alloys and austenitic steels, $\mathrm{M}_{23} \mathrm{C}_{6}$ carbide precipitated on dislocations causes creep strength to increase [27]. Accordingly,

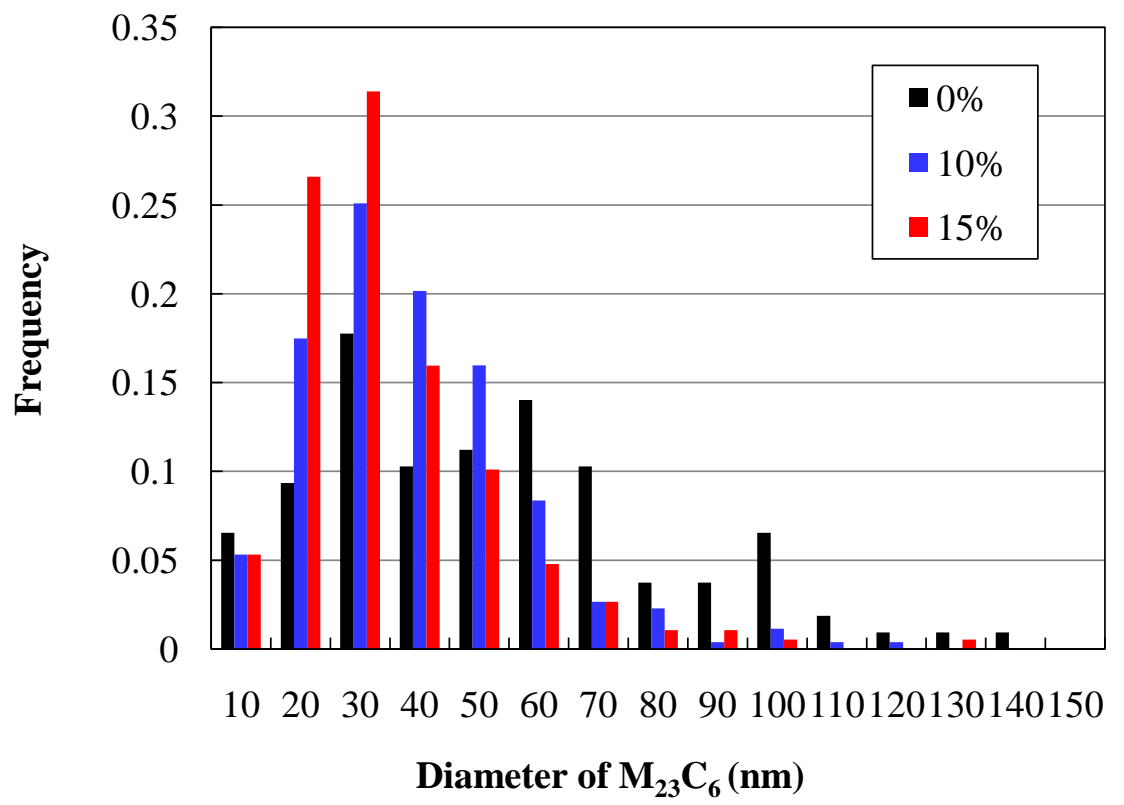

Figure 9. Histograms showing the distribution of diameters of $\mathrm{M}_{23} \mathrm{C}_{6}$ carbide in HR6W with and without pre-strain.

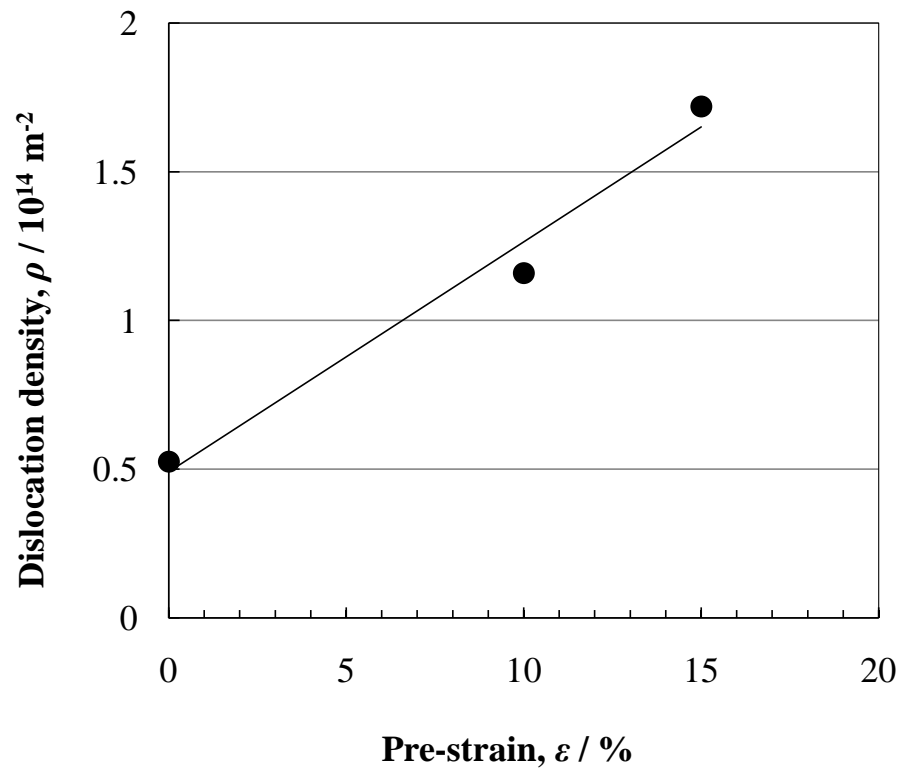

Figure 10. Change in the dislocation density with the amount of pre-strain in HR6W. 
It is suggested that $\mathrm{M}_{23} \mathrm{C}_{6}$ carbide in the pre-strained samples contributed to the creep strengthening more than in the non-pre-strained sample and acted as a factor in increasing the creep strength of the pre-strained samples.

In contrast to previous reports on pre-strained $\mathrm{Ni}$-base alloys or austenitic steels, the aggregation and coarsening of $\mathrm{M}_{23} \mathrm{C}_{6}$ carbide in the pre-strained HR6W were not observed during long time creep tests in this study. The reason why the size of $\mathrm{M}_{23} \mathrm{C}_{6}$ carbide remained fine for a long time is considered to be that $\mathrm{M}_{23} \mathrm{C}_{6}$ carbide is rich in $\mathrm{W}$ content (Figure 8). There are some reports that $\mathrm{W}$ concentrated in $\mathrm{M}_{23} \mathrm{C}_{6}$ carbide considerably delays the carbide coarsening [31] [32]. Yoshizawa et al. concluded that the reason for this delay is the effect of concentrated $\mathrm{W}$ in $\mathrm{M}_{23} \mathrm{C}_{6}$ carbide, some $\mathrm{Cr}$ atoms are replaced with $\mathrm{W}$ atoms, which exhibit a lower diffusion rate in iron than $\mathrm{Cr}$ atoms, and this replacement suppresses Ostwald ripening [32]. Then, quantitative EDX analysis on 30 pieces of $\mathrm{M}_{23} \mathrm{C}_{6}$ carbide was conducted and their diameters were calculated. Figure 11 shows the results of the calculations. It is found that fine $\mathrm{M}_{23} \mathrm{C}_{6}$ carbide tends to be rich in $\mathrm{W}$ content. In other words, much fine $\mathrm{M}_{23} \mathrm{C}_{6}$ carbide in the pre-strained samples tend to be richer in $\mathrm{W}$ content in $\mathrm{M}_{23} \mathrm{C}_{6}$ carbide than in the non-pre-strained sample. Accordingly, it is considered that for this alloy also, the rich $\mathrm{W}$ in the $\mathrm{M}_{23} \mathrm{C}_{6}$ carbide delayed the Ostwald ripening of carbide and contributed to the maintenance of the fine carbide for a long time. The grain size dependence of $\mathrm{W}$ content is probably caused by the Gibbs-Thomson effect. Since W content is larger when the size of $\mathrm{M}_{23} \mathrm{C}_{6}$ carbide is smaller, it is estimated that the size of carbide consequently maintained to be fine, delaying growth. The details of this matter need to be examined in the future.

\section{Conclusions}

In order to clarify the reason why the creep rupture time of pre-strained HR6W is longer than that of the non-pre-strained HR6W, microstructures of HR6W after a series of creep tests were investigated. The obtained results are as follows.

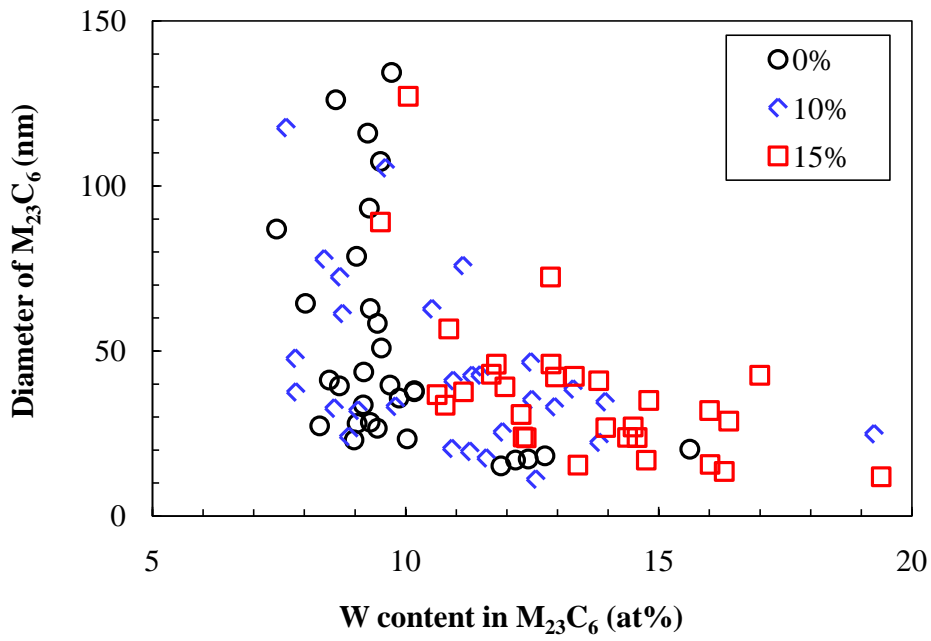

Figure 11. The relationship between $\mathrm{W}$ content in $\mathrm{M}_{23} \mathrm{C}_{6}$ carbide and its diameter. 
1) The grain boundary shielding ratio by precipitates in the pre-strained samples was higher than in the non-pre-strained sample. Therefore, it was considered that grain boundary strengthening by precipitates in the pre-strained samples acted more than in the non-pre-strained sample, increasing the creep rupture strength of the pre-strained samples.

2) Significant difference in the size of the Laves phase in the grains depending on pre-strain was not observed.

3) In the pre-strained samples the size of the $\mathrm{M}_{23} \mathrm{C}_{6}$ carbide in the grains was finer than in the non-pre-strained sample. Therefore, it is suggested that $\mathrm{M}_{23} \mathrm{C}_{6}$ carbide in the pre-strained samples contributed to the creep strengthening more than in the non-pre-strained sample and acted in increasing the creep strength of the pre-strained samples.

4) It is considered that the reason why the size of $\mathrm{M}_{23} \mathrm{C}_{6}$ carbide in the pre-strained samples remained fine for a long time is that the $\mathrm{W}$ content in the $\mathrm{M}_{23} \mathrm{C}_{6}$ carbide in the pre-strained samples tended to be larger than in the non-pre-strained sample.

From the above, it is considered that when the cold working is applied to HR6W, precipitation strengthening inside of the grains and grain boundaries effectively works, so that the creep strength significantly increases as compared with other Ni-based alloys.

\section{References}

[1] Kubushiro, K., Nomura, K., Matuoka, T., Nakagawa, H. and Muroki, K. (2016) Development of Boiler Technology for $700^{\circ} \mathrm{C}$ A-USC Plant. IHI Engineering Review, $49,34-43$

[2] Takano, S., Aoki, H., Kubushiro, K., Tomiyama, N. and Nakagawa, H. (2009) Development of 700 Degree Celsius Class Advanced Ultra-Supercritical Boiler. IHI Engineering Review, 49, 185-191. (In Japanese)

[3] Fukuda, M., Yoshida, T., Iseda, A., Semba, H., Saito, E., Kitamura, M., Dohi, T., Aoki, H., Muroki, K., Fukutomi, H., Sato, K., Satio, N., Hirakawa, Y., Nishii, T., Takahashi, T. and Matubara, Y. (2016) $700^{\circ} \mathrm{C}$ A-USC Technology Development in Japan. Proceedings of 8 th International Conference on Advances in Materials Tech nology for Fossil Power Plants, Algarve, 10-14 October 2016, 12-23.

[4] Fukuda, M. (2007) The Next Generation of USC Technology in Japan. Proceedings of International Conference on Power Engineering, Hagzhou, 23-27 October 2007, 20-25. https://doi.org/10.1007/978-3-540-76694-0_3

[5] Kubusiro, K., Nomura, K., Nakagawa, H., Ohkuma, Y. and Muroki, K. (2015) Development of Fabrication Technology for the A-USC Boiler. Proceedings of International Conference on Power Engineering, Yokohama, 30 November-4 December 2015.

[6] Abe, F. (2015) Research and Development of Heat-Resistant Materials for Advanced USC Power Plants with Steam Temperatures of $700^{\circ} \mathrm{C}$ and above. Engineering, 1, 211-224. https://doi.org/10.15302/J-ENG-2015031

[7] Umaki, H., Kajigaya, I., Kunihiro, T., Totsuka, T., Nakashiro, M. and Kume, T. (1991) Application of Large Diameter Seam Welded Pipes and Header of Super 9Cr Steel for $700 \mathrm{MW}$ Coal-Fired Boiler with $593^{\circ} \mathrm{C}$ Reheat Steam Temperature. Ishi- 
kawajima-Harima Engineering Review, 31, 339-345. (In Japanese)

[8] Semba, H., Okada, H., Hamaguti, T., Ishikawa, S. and Yoshizawa, M. (2013) Development of Boiler Tubes and Pipes for Advanced USC Power Plants. Nippon Steel \& Sumitomo Metal Technical Report, 397, 71-77. (In Japanese)

[9] Semba, H., Okada, H., Igarashi, M., Hirata, H. and Yoshizawa, M. (2010) Development of Fe-Ni and Ni-Base Alloys without $\gamma$ ' Strengthening for Advanced USC Boilers. Proceedings of 9 th Liege Conference on Materials for Advanced Power Engineering, Liège, 14-17 September 2014, 360-369.

[10] Furuta, T., Ogawa, Y. and Nagasaki, R. (1973) The Effect of Cold Working on Creep Properties of 316 Stainless Steel USED as a Fuel Cladding in Fast Breeder Reactors. Tetsu-to-Hagane, 59, 949-954. (In Japanese)

[11] Masuyama, F. (2007) Cold Work Effect on Creep Rupture Strength of Austenitic Boiler Steels. Proceedings of 8 th International Conference on Creep and Fatigue at Elevated Temperatures, CREEP 2007-26469. https://doi.org/10.1115/CREEP2007-26469

[12] Ogawa, K., Ishii, M., Yoshizawa, H., Oote, S. and Wada, Y. (1986) Pre-Strain Effect on the Elevated Temperature Mechanical Properties of Type 304 Stainless Steel. The Society of Materials Science, 35, 1284-1290. (In Japanese)

[13] Nakzawa, T. and Abo, H. (1977) The Effects of Some Factors on the Creep Behavior of Type 304 Stainless Steel. Tetsu-to-Hagane, 63, 1150-1159. (In Japanese) https://doi.org/10.2355/tetsutohagane1955.63.7_1150

[14] Saito, N. (2007) Creep Deformation Behavior and Microstructural Degradation during Creep of Pre-Strained 25Cr-20Ni-Nb-N Steel. Proceedings of 8 th International Conference on Creep and Fatigue at Elevated Temperatures, CREEP 2007-26764. https://doi.org/10.1115/CREEP2007-26764

[15] Okada, H., Semba, H., Ishikawa, S. and Yoshizawa, M. (2012) Effect of Cold Working on Creep Properties of a 23Cr-45Ni-7W Alloy. CAMP-ISIJ, 25, 405. (In Japanese)

[16] Saito, N., Komai, N., Hashimoto, K. and Kitamura, M. (2016) Long-Term Creep Rupture Properties and Microstructures in Hr6w (44Ni-23Cr-7W) for A-USC Boilers. Proceedings of 8 th International Conference on Advances in Materials Technology for Fossil Power Plants, 419-429.

[17] Kubushiro, K., Shioda, Y. and Nomura, K. (2017) Effect of Pre-Strain on the Creep Strength of Ni-Based Alloys for A-USC Boilers. Transactions of the Indian Institute of Metals, 70, 1261-1268. https://doi.org/10.1007/s12666-016-0919-3

[18] Nomura, K., Shioda, Y., Kubushiro, K., Nakagawa, H. and Murata, Y. (2017) Strain Analysis of Weld Joint of 23Cr-45Ni-7W Alloy by XRD and EBSD Method. Journal of the Society of Materials Science, 66, 51-57. (In Japanese) https://doi.org/10.2472/jsms.66.51

[19] Umezaki, S., Murata, Y., Nomura, K. and Kubushiro, K. (2014) Quantitative Analysis of Dislocation Density in an Austenitic Steel after Plastic Deformation. Journal of Japan Institute Metals, 78, 218-224. (In Japanese) https://doi.org/10.2320/jinstmet.J2014001

[20] Elbatahgy, A.M., Matsuo, T. and Kikuchi, M. (1990) Grain Boundary Precipitation Strengthening due to $\gamma$ Phase in High Temperature Creep of a Ni-Base Superalloy. Tetsu-to-Hagane, 76, 767-774. (In Japanese) https://doi.org/10.2355/tetsutohagane1955.76.5_767

[21] Kondo, Y., Ishizaki, A. and Namekata, J. (1990) Effect of Carbide Precipitation Formed on Dislocations along Grain Boundaries on High Temperature Creep Resistance of a Ni-30Cr Alloy. Tetsu-to-Hagan, 76, 1187-1194. (In Japanese) 
https://doi.org/10.2355/tetsutohagane1955.76.7_1187

[22] Tarigan, I., Takata, N. and Takeyama, M. (2012) Grain Boundary Precipitation Strengthening Mechanism by $\mathrm{Fe}_{2} \mathrm{Nb}$ Laves Phase in Creep of Fe-20Cr-30Ni-2Nb Austenitic Heat Resistant Steel. Proceedings of 12 th International Conference on Creep and Fracture of Engineering Materials and Structures (JIMIS 11).

[23] Kurata, K., Takata, N., Matsuo, T. and Takeyama, M. (2008) Effect of Grain Boundary Laves Phase $\mathrm{Fe}_{2} \mathrm{Nb}$ on Creep Resistance of Fe-20Cr-30Ni-2Nb Austenitic Heat Resistance Steel. Proceedings of Japan Society for Promotion of Science 123 rd Committee on Heat Resisting Materials and Alloys, 49, 379-390. (In Japanese)

[24] Tarigan, I., Kurata, K., Takata, N., Matsuo, T. and Takeyama, M. (2011) Novel Concept of Creep Strengthening Mechanism Using Grain-Boundary $\mathrm{Fe}_{2} \mathrm{Nb}$ Laves Phase in Austenitic Heat Resistant Steel. Materials Research Society Symposia Proceedings, 1295, 317-322. https://doi.org/10.1557/opl.2011.558

[25] Weiss, B. and Stickler, R. (1972) Phase Instabilities during High Temperature Exposure of 316 Austenitic Stainless Steel. Metallurgical Transactions, 3, 852-866. https://doi.org/10.1007/BF02647659

[26] Spruiell, J.E., Scottm, J.A., Ary, C.S. and Hardin, R.L. (1973) Microstructural Stability of Thermal-Mechanically Pretreated Type 316 Austenitic Stainless Steel. Metallurgical Transactions, 4, 1533-1544.

[27] Mino, K., Ohtomo, A. and Saiga, Y. (1977) Effect of Grain Boundary Migration and Recrystallization on the Creep Strength of Inconel 617. Tetsu-to-Hagane, 63, 2372-2380. (In Japanese) https://doi.org/10.2355/tetsutohagane1955.63.14_2372

[28] Trotter, G., Rayner, G., Baker, I. and Munroe, P.R. (2014) Accelerated Precipitation in the AFA Stainless steel $\mathrm{Fe}-20 \mathrm{Cr}-30 \mathrm{Ni}-2 \mathrm{Nb}-5 \mathrm{Al}$ via Cold Working. Intermetallics, 53, 120-128.

[29] Qilong, Y. (1990) Theory of Nucleation on Dislocations. Chin. J. Met. Sci. Technol., 6, 239-243.

[30] Fujii, T., Onaka, S. and Kato, M. (2004) Energy Consideration for Preferential Precipitation on Dislocations. Materia Japan, 43, 925-930. (In Japanese) https://doi.org/10.2320/materia.43.925

[31] Hald, J. (2008) Microstructure and Long-Term Creep Properties of 9-12\% Cr Steels. International Journal of Pressure Vessels and Piping, 85, 30-37.

[32] Yoshizawa, M., Igarashi, M. and Nishizawa, T. (2005) Effect of Tungsten on the Ostwald Ripening of $\mathrm{M}_{23} \mathrm{C}_{6}$ Carbides in Martensitic Heat Resistant Steel. Tetsu-to-Hagane, 91, 272-277. (In Japanese) https://doi.org/10.2355/tetsutohagane1955.91.2_272 